\title{
The Role of Literature in Enhancing Creative Writing from Teachers' Perspectives
}

\author{
Ahmed Abdalla Saeed Adam ${ }^{1} \&$ Yousif Omer Babiker ${ }^{2}$ \\ ${ }^{1}$ College of Arts and Science, Al-Baha University, Al-Mikhwa, Saudi Arabia \\ ${ }^{2}$ College of Languages, Sudan University of Science \&Technology, Khartoum, Sudan \\ Correspondence: Ahmed Abdalla Saeed Adam1 College of Arts and Science, Al-Baha University, Al-Mikhwa, \\ Saudi Arabia. Tel: 966-50-115-2130. E-mail: ahmad_saeed604@yahoo.com
}

\author{
Received: November 16, 2014 Accepted: December 29, 2014 Online Published: February 25, 2015 \\ doi:10.5539/ells.v5n1p109 \\ URL: http://dx.doi.org/10.5539/ells.v5n1p109
}

\begin{abstract}
The purpose of this study was to investigate the impact of teaching literature on developing creative writing from teachers' perspectives. To best understand English literature and be involved and equipped of carrying out such critical work or analysis it is essential to first consider how texts are written before they come into being. Therefore, this study investigates to establish a theoretical approach to undergraduate creative writing development through teaching English literature. The study sample consists of fifty English language university teachers. This paper presents the results from teachers' questionnaire. Generally, the results show that teaching English literature can enhance students' creative writing of short stories, dramatic scenes and develop creative imagination. The results also reveal that students develop their language use when writing. Teaching literature can also improve better use of literary techniques, figures of speech and literary elements in creative writing.
\end{abstract}

Keywords: teaching literature, creative writing, short stories, literary techniques, literary elements, figures of speech

\section{Introduction}

There is no doubt that the study and teaching of literature enhance the four language skills (reading, writing, listening and speaking). Reading literature from different periods adds to the understanding to human experiences and values. Teaching and reading different literary genres can contribute in enhancing students' creative writing. In this regard literature is considered to be the core of language learning. Here stems the need for further investigation for the role of English literature in enhancing creative writing short stories and dramatic scenes.

\subsection{The Statement of the Problem}

The relationship between English literature studies and creative writing is closely interrelated. This relationship is the prime purpose of the paper, for creative writing is the art of writing literature. To explore such correlation and how these relationships operate and help in understanding the literature of the past and benefit from that by producing new writings are the key questions of this study. Therefore, it will be attempted to investigate these relationships and underline the importance of the English literature and its role on enhancing creative writing skills.

Literature is seen as a resource which provides linguistic opportunities by providing essential language learning opportunities and help stimulating learners' personal intellectual growth through the encouragement of self awareness and perceiving the world around them. The learners are given information and the history of literature, traditions, heritage, nature of influences and the relationship between authors and context. On the other hand, literature within academic or institutionalized setting focuses on acquisition of qualification in literary studies. Critical concepts literary conventions are used instead in talking and writing about literature. In the following, different benefits of literature will be discussed.

In this context, there are many benefits in using literature where English is taught as second or foreign language. A part from offering a distinct and rich literary world and developing other skills, it can be used as a backup for developing creative writing skills. Frank (1995) asserted that literature is the best stimulator for creative writing. Therefore, Frank urges language educators to make it a vehicle for familiarizing their students with literature in 
all its forms. Frank believes that literature is the best means to stimulate and encourage students to write. Hence, he calls on teachers to use English literature for the development of their students' writing skills and make of them successful, creative professional writers.

\subsection{The Significance of the Problem}

This study is momentous because it investigates the role of English literature in enhancing creative writing. It examines and measures the correlation between teaching literature and developing creative writing in literature classes, as in either case creative writing is recognized as a basic component of the syllabus of literature in Sudanese universities. As well, it is considered a major field in the process of language and literature teaching. It is contended that the study can help literature teachers to develop new strategies and attitudes towards creative writing programmes and activities to foster creativity, artistic expression and writing skills. It can also help the teachers and the English language departments to adopt creative writing courses in literature classes to provide the students with essential materials and knowledge that will allow them to practise writing stories, poems and essays.

\subsection{Literature Review}

Morley, David (2007) points out that reading works of literature, such as novels and poems, is the reason behind the wish of many individuals to become a writer. McKay (1980) argues that literature will increase all language skills, for literature enhances linguistic knowledge by giving evidence of widespread and rich vocabulary usage and complex and exact syntax. Littlewood (1986) who observed that notwithstanding the fact that literary texts were predominantly valuable for developing language skills, it could further be exploited for the purposes of explaining grammar and indicating various types of language usage.

Likewise, Collie and Slater (1987) are in favor of the inclusion of literature in classroom language teaching. They claim that literature provides valuable authentic material and develops the students' personal participation and contributes to the enrichment of culture and language. O'Sullivan, (1991) believed that since literature has the power to develop the students' creativity and imagination, it is only natural to include it in language teaching. Principally, the aim of teaching literature is to increase the students' abilities and confidence through the study of literary texts.

Likewise, Lazar (1993) points out that literature should be seen as valuable resource of motivating material that would provide access to cultural background. Further, Lazar believes that literature enhances language acquisition, expands the students' language awareness and abilities of interpretation. She thinks that the use of literary texts in language teaching, provide the students with the cultural knowledge about the target language and its use in context. It also helps good interpretation. She believes that teaching literature can help to stimulate the imagination of learners, develop their critical abilities and increase their emotional awareness.

Smith, Hazel (2006) asserts that creative writing used to be treated like a poor relation to literary studies within higher education. Literary texts were the prime object of attention, and students were given no opportunity to write such texts themselves. Even for the benefit of literary study this was unfortunate, because it is possible to learn a great deal about literary texts by creating them. To understand the activity of writing is to appreciate more the writers' work, the choices they make and their use of language. Writing is often a means of becoming a more informed and critical reader.

Stern (2001) has also supported the view that literature can be a rich and inspiring source for writing; both as a model and as a subject matter. Literature as a model can be found in the students' writings which will closely resemble the original works or great literary writers or imitate the content, theme, organization or style. Literature as a subject matter can be displayed by the students in their demonstration of original thinking, interpretation or analysis all of which may have evolved from or have been inspired by the literary works they have read. Stern believes that the learners' writing is better improved when they are exposed to literary texts.

Oster (1989) asserts that literature exposes the learners to coherent and expert writing which fact helps in better writing. Reading literary texts by different authors is believed to introduce the learners to different writing styles; and this will, in turn, insight learners and encourage them to develop their own writing styles.

To stress the importance of creative writing to the students' achievements, Tompkins (1982) points out that there are seven reasons for requiring the students to write stories and poetry: To foster artistic expressions, to explore the functions and value of writing, to stimulate imagination, to clarify thinking, to search for identity and to learn to read and write.

Creative writing enhances the general writing skills among students. Richards, (1990) points out that writing is a requirement at every level of the students' academic pursuit and is not entirely limited to language and 
literature .This serves the objective of writing programmes, which is to enable the students to produce different kinds of writings.

Creative writing develops critical reading skills. In support of this, Kramsch (1993) has observed that creative writing leads to more creative reading. By being engaged with what they are writing the learners are expected to reach the level of intuitive understanding of how the texts function, which fact makes similar texts easier to read.

Bastrukmen and Lewis (2002) assert that the notion of success in learning English creative writing is associated with self-expressions, the flow of ideas, outsider expectations, growing confidence and enjoyment of academic writing. They believe that good writing involves the ability to express ideas clearly and confidently to readers. Also, they stress that creative writing enables the students to express themselves more efficiently and with great confidence.

\subsection{Objectives of the Study}

The objectives of the study are set to:

a. explore the role of teaching literature in developing creative writing among English language major undergraduates.

b. suggest methods of studying and reading literary texts which lead to enhancing creative writing development.

\subsection{Questions of the Study}

To achieve the objectives of the study, the researchers attempt to answer the following research Questions:

1. To what extent does English literature enhance creative writing and develop students' creative imagination?

2. Which types of activities and approaches should be employed by literature teachers to develop creative writing skills?

3. To what extent, does creative writing contribute to students' language development?

\section{Materials and Methods}

\subsection{Data Gathering Tool}

It is assumed that teachers' questionnaire and students' pre and post-tests are the most appropriate tools for this study. Therefore, teachers' questionnaire of the five scale likert -type was used to collect data. The questionnaire is constructed to teachers of English language and literature to give responses to the items of the questionnaire and express their opinions.

\subsection{Subject Characteristics}

The original population of this study is all of the teachers of English language and literature at the two specific universities; in addition to some experts in the field of English language teaching from other Sudanese universities. The participants are either literature specialists or taught literature courses at university level.

\subsection{Sampling Procedure}

Teachers from two Sudanese universities participated in this study (Sudan university of Science \&Technology and Ahfad University for Women).There are some experts in the field of English literature from other Sudanese universities have participated due to the limited numbers of English Language and literature teachers. The simple random sampling procedure is used to select fifty teachers.

\subsection{Sample Size}

Originally, there were75 distributed questionnaires, only fifty questionnaire were received with full-required information. Most of these participants are either from University of Science and Technology or Ahfad University for Women.

\section{Results and Discussion}

Below are teachers' responses to the questionnaire about the role of teaching English literature in developing students' creative writing. The study is set to answer the stated research questions. Therefore, it will be appropriate to demonstrate the results of the teachers' questionnaire in detail. This includes teachers' responses to the different items of each statement: 
Table 1. Teachers' views on the role of literature in developing students' creative writing and creative imagination

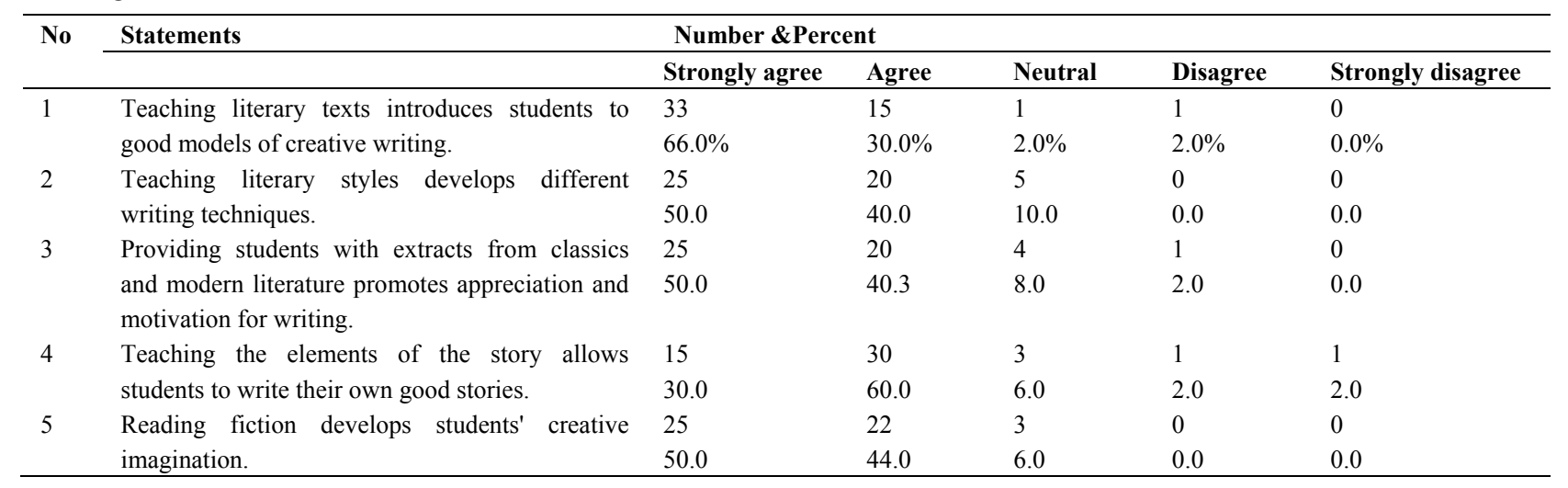

Teachers' opinions on the results related to the first hypothesis about the role of teaching literature in developing students' creative writing and creative imagination is shown in table 1.

In this table there are 48 teachers representing $96 \%$ agreed that "Teaching literary texts introduce students to good models of creative writing". Only one respondent (2.0\%) is neutral, and one student with $(2.0 \%)$ disagree.

As for the second statement 25 teachers in the study sample $(50.0 \%)$ strongly agreed that "Teaching literary styles develops different writing techniques". 20 teachers $(40.0 \%)$ agree with the statement, and 5 teachers $(10.0 \%)$ were neutral.

As for the third item, there are 25 teachers representing the study sample $(50.0 \%)$ strongly agree with the set statement. 20 respondents $(40.0 \%)$ positively agree, 4 teachers $(8.0 \%)$ are neutral and only one teacher $(2.0 \%)$ is against.

Responses to item 4 shows that 15 teachers (30.0\%) agree with the set statement; while 30 participants (60.0\%) agree and 3 teachers $(6.0 \%)$ took a neutral stand. Only one respondent $(2.0 \%)$ disagree.

Regarding the fifth statement 8 teachers (11.1\%) strongly agreed, 22 teachers $(44.0 \%)$ agreed on that and 3 participants $(6.0 \%)$ took a neutral stand.

From the above results, it is clear that the first hypothesis is highly agreed upon by most of the respondents.

An indication of this result, is that $(96 \%)$ of the participating teachers agreed that teaching literary texts introduce students to good models of creative writing; and (90\%) of the respondents agreed that teaching literary styles develops different writing techniques. And (90\%) of the teachers believed that providing students with extracts from classics and modern literature promotes their appreciation and motivation for writing; while there were $(90 \%)$ of the respondents agreed that teaching the elements of the stories allows students to write their own good stories. Finally, more than $(55 \%)$ of the teachers agreed that reading fiction develops students' creative imagination.

Table 2. Teachers responses on the ways that literature can be exploited in developing students' creative writing

\begin{tabular}{|c|c|c|c|c|c|c|}
\hline \multirow[t]{2}{*}{ No } & \multirow[t]{2}{*}{ Statements } & \multicolumn{5}{|c|}{ Number \&Percent } \\
\hline & & Strongly agree & Agree & Neutral & Disagree & Strongly disagree \\
\hline \multirow[t]{2}{*}{6} & \multirow{2}{*}{$\begin{array}{l}\text { Teaching students the figures of speech is } \\
\text { useful in developing creative writing. }\end{array}$} & 6 & 20 & 24 & 0 & 0 \\
\hline & & 12.0 & 40.0 & 48.0 & 0.0 & 0.0 \\
\hline \multirow[t]{2}{*}{7} & \multirow{2}{*}{$\begin{array}{l}\text { Exposing students to different literary genres } \\
\text { provides background for good writing. }\end{array}$} & 23 & 23 & 3 & 1 & 0 \\
\hline & & 46.0 & 46.0 & 6.0 & 2.0 & 0.0 \\
\hline \multirow[t]{2}{*}{8} & \multirow{2}{*}{$\begin{array}{l}\text { Engaging student in paraphrasing poems } \\
\text { improve their abilities to write. }\end{array}$} & 15 & 27 & 6 & 1 & 1 \\
\hline & & 30.0 & 54.0 & 12.0 & 2.0 & 2.0 \\
\hline \multirow[t]{2}{*}{9} & \multirow{2}{*}{$\begin{array}{l}\text { Using literature circles facilitates and } \\
\text { develops students writing. }\end{array}$} & 9 & 28 & 10 & 2 & 1 \\
\hline & & 18.0 & 56.0 & 20.0 & 4.0 & 2.0 \\
\hline \multirow[t]{2}{*}{10} & \multirow{2}{*}{$\begin{array}{l}\text { Critical approach to works of literature } \\
\text { improves literary understanding. }\end{array}$} & 24 & 22 & 2 & 2 & 0 \\
\hline & & 48.0 & 44.0 & 4.0 & 4.0 & 0.0 \\
\hline
\end{tabular}


Teachers' responses to hypothesis 2 are shown in table 2:

Responses to item 6 revealed that 6 teachers in the study sample $(12.0 \%)$ agreed with the statement. 20 participants $(40.0 \%)$ responded with agree, 24 teachers $(48.0 \%)$ took a neutral stand.

Responses to item 7 showed that 23 teachers in the study sample (46.0\%) strongly agreed, while 23 respondents (46.0\%) agreed. Only 3 teachers $(6.0 \%)$ were neutral, and only one participant with $(2.0 \%)$ disagreed.

Regarding the statement 8 there were 15 teachers in the study sample (30.0\%) who strongly agreed with the set statement, 27 teachers $(54.0 \%)$ agreed and 6 respondents $(12.0 \%)$ were neutral. Only one teacher $(2.0 \%)$ disagreed, and only one respondent (2.0\%) strongly disagreed.

As for statement 9 , (9) teachers in the study sample (18.0\%) strongly agreed with the stated item. 28 respondents $(56.0 \%)$ agreed 10 teachers $(20.0 \%)$ were neutral. On the other hand, 2 teachers $(4.0 \%)$ disagreed, and only one person $(2.0 \%)$ strongly disagreed.

Statement 10, states that 24 teachers in the study sample (48.0\%) strongly agreed with the set statement 22 respondents (44.0\%) agreed, And 2 teachers (4.0\%) were neutral. 2 respondents $(4.0 \%)$ have disagreed.

According to what is shown in table (4:4) the results can be demonstrated as follows:

To sum up the teachers responses hypothesis $2,(52 \%)$ agreed that teaching students the figures of speech is useful in developing creative writing and (92\%) of the respondents believed that exposing students to different literary genres provides background for good writing. And (84\%), of the teachers thought that engaging students in paraphrasing poems improves their abilities to write. Also (74\%) of the teachers agreed that using literature circles facilitates help and develop the students' creative writing. Finally, (92\%) of the teachers believed that the critical approach to works of literature improves literary understanding.

Table 3. Teachers' views and opinions on the activities and approaches that can be used by literature teachers to develop creative writing

\begin{tabular}{|c|c|c|c|c|c|c|}
\hline \multirow[t]{2}{*}{ No } & \multirow[t]{2}{*}{ Statements } & \multicolumn{5}{|c|}{ Number \&Percent } \\
\hline & & Strongly agree & Agree & Neutral & Disagree & Strongly disagree \\
\hline \multirow[t]{2}{*}{11} & Class discussion is a good method for & 32 & 9 & 8 & 1 & 0 \\
\hline & developing topics for creative writing. & 64.0 & 18.0 & 16.0 & 2.0 & 0.0 \\
\hline \multirow[t]{2}{*}{12} & It is important to ask students to write & 17 & 23 & 8 & 2 & 0 \\
\hline & short stories and poems. & 34.0 & 46.0 & 16.0 & 4.0 & 0.0 \\
\hline \multirow[t]{2}{*}{13} & Creative writing assignments are & 11 & 30 & 7 & 2 & 0 \\
\hline & essential for teaching literature. & 22.0 & 60.0 & 14.0 & 4.0 & 0.0 \\
\hline \multirow[t]{2}{*}{14} & Creative writing workshops allow & 18 & 24 & 7 & 1 & 0 \\
\hline & students to write freely. & 36.0 & 48.0 & 14.0 & 2.0 & 0.0 \\
\hline \multirow[t]{2}{*}{15} & Asking students to write freely during & 30 & 17 & 3 & 0 & 0 \\
\hline & $\begin{array}{l}\text { literature courses improves creative } \\
\text { writing. }\end{array}$ & 60.0 & 34.0 & 6.0 & 0.0 & 0.0 \\
\hline
\end{tabular}

Table 3 shows the teachers' views on the activities and approaches that can be used by literature teachers to develop creative writing.

Responses to statement 11 in hypothesis 3 showed that 32 teachers in the study sample $(64.0 \%)$ strongly agreed with the set statement 9 respondents $(18.0 \%)$ agreed with the statement 8 teachers $(16.0 \%)$ were neutral, only one person $(2.0 \%)$ disagreed.

As for statement 12,17 teachers in the study sample (34.0\%) strongly agreed. 23 respondents $(46.0 \%)$ agreed and 8 teachers $(16.0 \%)$ were neutral, while 2 respondents $(4.0 \%)$ disagreed.

Responses to statement 13 showed that 11 teachers in the study sample (22.0\%) strongly agreed with the set statement. 30 respondents $(60.0 \%)$ agreed, and 7 teachers $(14.0 \%)$ were neutral. Only one respondent $(2.0 \%)$ disagreed, and 2 teachers $(4.0 \%)$ strongly disagreed.

In the statement 14,18 teachers in the study sample (36.0\%) strongly agreed with the set statement. 24 respondents $(48.0 \%)$ agreed, and 7 teachers $(14.0 \%)$ were neutral. On the other hand, one participant $(2.0 \%)$ disagreed.

Responses to statement 15 , show that 30 teachers in the study sample $(60.0 \%)$ strongly agreed with the statement. 17 respondents (34.0\%) agreed, and 3 
To sum up the results concerning hypothesis $2,(82 \%)$ of the teachers agreed that class discussion is a good method for developing topics for creative writing, and $(80 \%)$ of the respondents believed that it is important to ask students to write short stories and poems, while (82\%) thought that creative writing assignments are essential for teaching literature, and ( $84 \%)$ believed that creative writing workshops allow students to write freely. (94\%) of the teachers believed that asking students to write freely during literature courses improves their creative writing.

Table 4. Teachers views on the contribution of creative writing to students' language development

\begin{tabular}{|c|c|c|c|c|c|c|}
\hline \multirow[t]{2}{*}{ No } & \multirow[t]{2}{*}{ Statements } & \multicolumn{5}{|c|}{ Number \& Percent } \\
\hline & & Strongly agree & Agree & Neutral & Disagree & Strongly disagree \\
\hline \multirow[t]{2}{*}{16} & Creative writing develops language proficiency. & 28 & 19 & 2 & 1 & 0 \\
\hline & & 56.0 & 38.0 & 4.0 & 2.0 & 0.0 \\
\hline \multirow[t]{2}{*}{17} & Writing stories engages students in writing & 16 & 24 & 10 & 0 & 0 \\
\hline & $\begin{array}{l}\text { complex syntactic structures and paragraphing } \\
\text { which enhances knowledge of grammar. }\end{array}$ & 32.0 & 48.0 & 20.0 & 0.0 & 0.0 \\
\hline \multirow[t]{2}{*}{18} & Writing and reading poetry helps develop & 8 & 27 & 11 & 4 & 0 \\
\hline & pronunciation. & 16.0 & 54.0 & 22.0 & 8.0 & 0.0 \\
\hline \multirow[t]{2}{*}{19} & Creative writing improves critical reading. & 15 & 18 & 12 & 5 & 0 \\
\hline & & 30.0 & 36.0 & 24.0 & 10.0 & 0.0 \\
\hline \multirow[t]{2}{*}{20} & Writing short stories promotes artistic expression & 25 & 24 & 1 & 0 & 0 \\
\hline & among student. & 50.0 & 48.0 & 2.0 & 0.0 & 0.0 \\
\hline
\end{tabular}

Teachers' views about the importance of creative writing to the students' language development is demonstrated as shown in table 4:

In the statement 16,28 teachers in the study sample (56.0\%) strongly agreed with the set statement. 19 respondents $(38.0 \%)$ agreed and 2 teachers $(4.0 \%)$ were neutral, while one respondent $(2.0 \%)$ disagreed.

Regarding statement 17,16 respondents in the study sample (32.0\%) strongly agreed 24 participants (48.0\%) agreed with set statement, 10 teachers $(20.0 \%)$ were neutral.

Responses to statement 18 show that 8 teachers in the study sample (16.0\%) strongly agreed with the set statement, 27 respondents $(54.0 \%)$ agreed, 11 participants $(22.0 \%)$ were neutral, while 4 respondents $(8.0 \%)$ disagreed.

Regarding statement 19, 15 teachers in the study sample (30.0\%) strongly agreed with the set statement 18 respondents with the percentage of (36.0\%) agreed, and 12 of them $(24.0 \%)$ were neutral. 5 teachers $(10.0 \%)$ disagreed.

Responses to statement 20 showed that 25 teachers in the study sample $(50.0 \%)$ strongly agreed with the proposition that "Writing short stories increases artistic expression among student". 24 respondents (48.0\%) agreed, and only one person at the percentage of $(2.0 \%)$ was neutral about that idea.

To sum up, the teachers' responses to the role of creative writing on students' language development, showed that (94\%) of the respondents believed that creative writing develops language proficiency, while (80\%) thought that writing stories engages students in writing complex syntactic structures and good paragraphing which consolidates grammar knowledge. Also, approximately $(70 \%)$ of the respondents agreed that writing and reading poetry improves pronunciation; and (66\%) of the teachers believed that creative writing improves critical reading and $(98 \%)$ of them agreed that writing short stories increases artistic expression among students. 
Table 5. Teachers perception and attitudes to literature

\begin{tabular}{|c|c|c|c|c|c|c|}
\hline \multirow[t]{2}{*}{ No } & \multirow[t]{2}{*}{ Statements } & \multicolumn{5}{|c|}{ Number \&Percent } \\
\hline & & Strongly agree & Agree & Neutral & Disagree & Strongly disagree \\
\hline \multirow[t]{2}{*}{21} & Teaching literature stimulates students' creative and & 38 & 10 & 2 & 0 & 0 \\
\hline & $\begin{array}{l}\text { literary imagination and develops their appreciation } \\
\text { of literature. }\end{array}$ & 76.0 & 20.0 & 4.0 & 0.0 & 0.0 \\
\hline \multirow[t]{2}{*}{22} & In the process of teaching and learning English, & 29 & 18 & 2 & 1 & 0 \\
\hline & language and literature are inseparable. & 58.0 & 36.0 & 4.0 & 2.0 & 0.0 \\
\hline \multirow[t]{2}{*}{23} & Teaching language through literature makes learning & 25 & 22 & 2 & 1 & 0 \\
\hline & and teaching more interesting. & 50.0 & 44.0 & 4.0 & 2.0 & 0.0 \\
\hline \multirow[t]{2}{*}{24} & Using literary texts for the task of developing & 31 & 14 & 4 & 1 & 0 \\
\hline & $\begin{array}{l}\text { language skills is more stimulating than ordinary } \\
\text { textbooks. }\end{array}$ & 62.0 & 28.0 & 8.0 & 2.0 & 0.0 \\
\hline \multirow[t]{2}{*}{25} & Teaching literature develops the use of language in & 36 & 10 & 2 & 2 & 0 \\
\hline & $\begin{array}{l}\text { context, and helps transmit the culture of the target } \\
\text { language. }\end{array}$ & 72.0 & 20.0 & 4.0 & 4.0 & 0.0 \\
\hline
\end{tabular}

According to table 5, the results are demonstrated as follows:

38 respondents in the study sample (76.0\%) strongly agreed with the set statement. 10 teachers $(20.0 \%)$ agreed, and only 2 respondents $(4.0 \%)$ were neutral.

Regarding statement 22, 29 teachers in the study sample (58.0\%) strongly agreed, and 18 participants (36.0\%) agreed, while only 2 teachers $(4.0 \%)$ were neutral. Only one respondent $(2.0 \%)$ disagreed with that statement.

With regard to statement 23,25 teachers in the study sample (50.0\%) strongly agreed, while 22 respondents $(44.0 \%)$ agreed , and 2 teachers $(4.0 \%)$ were neutral . Only one respondent $(2.0 \%)$ disagreed.

In response to statement 24,31 teachers in the study sample $(62.0 \%)$ strongly agreed with the proposed statement, and 14 respondents $(28.0 \%)$ agreed, while 4 teachers $(8.0 \%)$ were neutral. Only one participant $(2.0 \%)$ disagreed.

In response to statement 25,36 teachers in the study sample (72.0\%) strongly agreed, 10 respondents $(20.0 \%)$ just agreed, while 2 teachers $(4.0 \%)$ were neutral. Only 2 participants $(4.0 \%)$ disagreed.

$(96 \%)$ of the respondents believed that teaching literature stimulates students' creative and literary imagination and develops their appreciation of literature, while (94\%) of the respondents believed that language and literature are inseparable in the process of teaching and learning English. (94\%) of the respondents thought that teaching language through literature makes learning and teaching more interesting; and (90\%) of the teachers believed that using literary texts for the task of developing language skills is more stimulating than ordinary textbooks, and $(82 \%)$ of the teachers believed that teaching literature develops the use of language in context, and it transmits the culture of the target language.

To sum up the survey of university English language and literature professors and instructors demonstrates that literature is a good stimulator for developing creative writing, and when taught properly the study of literature will trigger the learners' creative imagination. Teaching different genres of literature and different types of figures of speech along with activation of literature circles and the adoption of teaching different critical theories will provide the students' needed and essential backup for improving creative writing skills and literary appreciation. In addition, it was shown that teachers believed that class discussions, writing workshops and creative writing tasks assigned by literature professors and instructors, help improve creative writing by the students.

With regard to the role of creative writing to students' language development, most teachers believed that creative writing develops students' language proficiency, engages students in writing more complex syntactic structures. In addition, teachers agreed that reading and writing poetry leads to better pronunciation, hence the enhancement of their oral productive skills.

Finally, a survey of the teachers' attitude showed that university professors and instructors had similar attitudes to the importance of literature in developing language skills and language proficiency. The teachers agreed that teaching literature is the core of the language learning process. Therefore, language and literature cannot be separated in the process of teaching English as a second or foreign language. Their belief was based on the assumption that literature develops the students' creative imagination and enhances their use of the language in context. 
In addition, the results also demonstrate that literature is essential in developing the four language skills and language proficiency. To enhance such attitudes it is remarkable to utilize literature perfectly in the process of teaching English as a second or foreign language. And to provide a solid ground for students to appreciate and understand literature, teachers of literature are urged to ask students to write their own stories and poems. By practising creative writing students will be apt to understand literature in depth and this helps in developing language proficiency and literary appreciation.

\section{Conclusion}

According to teachers' evaluation the results confirm that teaching literature enhances students' creative writing skills and develops their imagination. This could be achieved through teaching different genres of literature that introduce students to the best models and writing styles that provide students with good background for creative writing. Providing students with extracts from classic and modern literature that would help in promoting their appreciation to literature and increase their motivation to writing stories and poems is also confirmed. Teachers also advocate for the use of short stories and reading fictional stories that enhance good writing and develop creative imagination. This can be achieved by engaging students in the world of some imaginary scenes and dilemmas which help in building students' imagination.

The analysis and the results of the teachers' questionnaire, show that there is a great awareness among teachers on the benefits of using literature for the sake of developing students' creative writing at university level. The vision of the professors and English language instructors is to expose students to different literary genres, figures of speech, paraphrasing poems would all participate in developing students' creativity in writing. Teachers are also encouraging the use of literature circles in the tasks of literature class discussions and exposing students to critical literary theories.

As for teachers' vision, the study result reveals that class discussion during literature courses can be a good method for developing topics for writing. In addition, writing short stories and simple poems, and writing workshops are useful methods that develop creative writing.

As for the role of creative writing on learners' language development, the teachers' questionnaire results show that creative writing contributes to promoting students' language proficiency. The study reveals that writing stories engages students in writing complex syntactic structures and deepens grammatical knowledge. Creative writing also improves critical reading and foster students' artistic expressions.

University teachers' have marvelous attitude towards the impact of teaching literature in developing students language proficiency and literary understanding. The study reveals that teaching language through literature makes learning and teaching more interesting. Using literary texts for the tasks of developing language skills is more stimulating than ordinary textbooks. Literature also develops the use of language in context since it transmits the culture of the target language.

\section{References}

Bastrukmen, H., \& Lewis, M. (2002). Learner perspectives of success in an EAP writing Course. The University of Auckland, New Zealand: Assessing Writing, 8(1), 31-46. http://dx.doi.org/10.1016/S1075-2935(02)00032-6

Collie, J., \& Slater, S. (1987). Literature in the Language Classroom. Cambridge: Cambridge University Press. http://dx.doi.org/10.1017/CBO9780511733048

Frank, M. (1995). If you are trying to teach kids how to write ... you've gotta have this book! ( $2^{\text {nd }}$ ed.). Nashville, TN: Incentive Publications.

Kramsch, C. (1993). Context and Culture in Language Teaching. Oxford: Oxford University Press.

Lazar, G. (1993). Literature and Language Teaching: A Guide for teachers and trainers. Cambridge: Cambridge University Press.

Littlewood, W. T. (1986). Literature in the school foreign-language course. In C. J. Brumfit \& R. A. Carter (Eds.), Literature and language teaching (pp. 177-183). Oxford: Oxford University Press.

McKay, S. (1980). Literature in ESL classroom. In Brumfit \& Carter (Eds.), Literature and Language teaching. Oxford: OUP.

Morley, D. (2007). The Cambridge Introduction to Creative Writing. Cambridge University press.

Oster, J. (1989). Seeing with different eyes: Another view of literature in the ESL class. TESOL Quarterly, 23(1), 85-103. http://dx.doi.org/10.2307/3587509 
O' Sullivan, R. (1991). Literature in the language classroom. The English Teacher, 20. Retrieved from http://www.melta.org.my/ET/1991/main6.html.

Richards, J. (1990). The language teaching matrix. Cambridge: Cambridge University Press. http://dx.doi.org/10.1017/CBO9780511667152

Smith, H. (2006). Emerging from the experiment: a systematic methodology for creative writing teaching. New writing: the International Journal for the practice and theory of creative writing, 3(1), 17-34. http://dx.doi.org/10.2167/new229.0

Stern, S. L. (2001). An integrated Approach to Literature in ESL/EFL. In Marianna Celece-Murcia (Ed.), Teaching English as a second or Foreign Language.

Tompkins, G. E. (1982). Seven Reasons Why Children Should Write Stories. Language Arts, 59(7), 718-721.

\section{Appendix A}

\section{Teachers' Questionnaire}

\section{Dear Colleagues;}

This questionnaire is intended to collect data for a scientific research.The aim of this study is to investigate the importance of teaching literature in developing creative writing among English major university students. The information provided will remain confidential and will be used only for the intended research purpose.

You are kindly requested to tick the response which better suits your opinion:

1. Teachers' views on the role of literature in developing students' creative writing and creative imagination

\begin{tabular}{|c|c|c|c|c|c|c|}
\hline \multirow[t]{2}{*}{ No } & \multirow[t]{2}{*}{ Statements } & \multicolumn{5}{|c|}{ Number \&Percent } \\
\hline & & Strongly agree & Agree & Neutral & Disagree & Strongly disagree \\
\hline 1 & $\begin{array}{l}\text { Teaching literary texts introduces students to good } \\
\text { models of creative writing. }\end{array}$ & & & & & \\
\hline 2 & $\begin{array}{l}\text { Teaching literary styles develops different writing } \\
\text { techniques. }\end{array}$ & & & & & \\
\hline 3 & $\begin{array}{l}\text { Providing students with extracts from classics and } \\
\text { modern literature promotes appreciation and } \\
\text { motivation for writing. }\end{array}$ & & & & & \\
\hline 4 & $\begin{array}{l}\text { Teaching the elements of the story allows students to } \\
\text { write their own good stories. }\end{array}$ & & & & & \\
\hline 5 & $\begin{array}{l}\text { Reading fiction develops students' creative } \\
\text { imagination. }\end{array}$ & & & & & \\
\hline
\end{tabular}

2. Teachers responses on the ways that literature can be exploited in developing students' creative writing

\begin{tabular}{|c|c|c|c|c|c|c|}
\hline \multirow[t]{2}{*}{ No } & \multirow[t]{2}{*}{ Statements } & \multicolumn{5}{|c|}{ Number \&Percent } \\
\hline & & Strongly agree & Agree & Neutral & Disagree & Strongly disagree \\
\hline 6 & $\begin{array}{l}\text { Teaching students the figures of speech is useful in } \\
\text { developing creative writing. }\end{array}$ & & & & & \\
\hline 7 & $\begin{array}{l}\text { Exposing students to different literary genres provides } \\
\text { background for good writing. }\end{array}$ & & & & & \\
\hline 8 & $\begin{array}{l}\text { Engaging student in paraphrasing poems improve their } \\
\text { abilities to write. }\end{array}$ & & & & & \\
\hline 9 & $\begin{array}{l}\text { Using literature circles facilitates and develops } \\
\text { students writing. }\end{array}$ & & & & & \\
\hline 10 & $\begin{array}{l}\text { Critical approach to works of literature improves } \\
\text { literary understanding. }\end{array}$ & & & & & \\
\hline
\end{tabular}


3. Teachers' views and opinions on the activities and approaches that can be used by literature teachers to develop creative writing

\begin{tabular}{|c|c|c|c|c|c|c|}
\hline \multirow[t]{2}{*}{ No } & \multirow[t]{2}{*}{ Statements } & \multicolumn{5}{|c|}{ Number \&Percent } \\
\hline & & Strongly agree & Agree & Neutral & Disagree & Strongly disagree \\
\hline 11 & $\begin{array}{l}\text { Class discussion is a good method for developing } \\
\text { topics for creative writing. }\end{array}$ & & & & & \\
\hline 12 & $\begin{array}{l}\text { It is important to ask students to write short stories and } \\
\text { poems. }\end{array}$ & & & & & \\
\hline 13 & $\begin{array}{l}\text { Creative writing assignments are essential for teaching } \\
\text { literature. }\end{array}$ & & & & & \\
\hline 14 & $\begin{array}{l}\text { Creative writing workshops allow students to write } \\
\text { freely. }\end{array}$ & & & & & \\
\hline 15 & $\begin{array}{l}\text { Asking students to write freely during literature } \\
\text { courses improves creative writing. }\end{array}$ & & & & & \\
\hline
\end{tabular}

4. Teachers views on the contribution of creative writing to students' language development

\begin{tabular}{|c|c|c|c|c|c|c|}
\hline \multirow[t]{2}{*}{ No } & \multirow[t]{2}{*}{ Statements } & \multicolumn{5}{|c|}{ Number \&Percent } \\
\hline & & Strongly agree & Agree & Neutral & Disagree & Strongly disagree \\
\hline 16 & Creative writing develops language proficiency. & & & & & \\
\hline 17 & $\begin{array}{l}\text { Writing stories engages students in writing complex } \\
\text { syntactic structures and paragraphing which enhances } \\
\text { knowledge of grammar. }\end{array}$ & & & & & \\
\hline 18 & $\begin{array}{l}\text { Writing and reading poetry helps develop } \\
\text { pronunciation. }\end{array}$ & & & & & \\
\hline 19 & Creative writing improves critical reading. & & & & & \\
\hline 20 & $\begin{array}{l}\text { Writing short stories promotes artistic expression } \\
\text { among student. }\end{array}$ & & & & & \\
\hline
\end{tabular}

5. Teachers perception and attitudes to literature

\begin{tabular}{|c|c|c|c|c|c|c|}
\hline \multirow[t]{2}{*}{ No } & \multirow[t]{2}{*}{ Statements } & \multicolumn{5}{|c|}{ Number \&Percent } \\
\hline & & Strongly agree & Agree & Neutral & Disagree & Strongly disagree \\
\hline 21 & $\begin{array}{l}\text { Teaching literature stimulates students' creative and } \\
\text { literary imagination and develops their appreciation of } \\
\text { literature. }\end{array}$ & & & & & \\
\hline 22 & $\begin{array}{l}\text { In the process of teaching and learning English, } \\
\text { language and literature are inseparable. }\end{array}$ & & & & & \\
\hline 23 & $\begin{array}{l}\text { Teaching language through literature makes learning } \\
\text { and teaching more interesting. }\end{array}$ & & & & & \\
\hline 24 & $\begin{array}{l}\text { Using literary texts for the task of developing language } \\
\text { skills is more stimulating than ordinary textbooks. }\end{array}$ & & & & & \\
\hline 25 & $\begin{array}{l}\text { Teaching literature develops the use of language in } \\
\text { context, and helps transmit the culture of the target } \\
\text { language. }\end{array}$ & & & & & \\
\hline
\end{tabular}

\section{Copyrights}

Copyright for this article is retained by the author(s), with first publication rights granted to the journal.

This is an open-access article distributed under the terms and conditions of the Creative Commons Attribution license (http://creativecommons.org/licenses/by/3.0/). 